\title{
Colored Microbial Coatings in Show Caves from the Galapagos Islands (Ecuador): First Microbiological Approach
}

\author{
Ana Z. Miller ${ }^{1,2, *,+}$ (i), Angela M. García-Sánchez ${ }^{3,+}{ }^{(\mathbb{D}}$, Mathilda L. Coutinho ${ }^{1}$, \\ Manuel F. Costa Pereira ${ }^{4}$ (D), Fernando Gázquez ${ }^{5}$ (D), José M. Calaforra ${ }^{5}$, Paolo Forti ${ }^{6}$, \\ Jesús Martínez-Frías ${ }^{7}$, Theofilos Toulkeridis ${ }^{8}$, Ana T. Caldeira ${ }^{1,9,10} \mathbb{D}$ and Cesareo Saiz-Jimenez ${ }^{2}$ \\ 1 HERCULES Laboratory, Universidade de Évora, 7000-809 Évora, Portugal; magldc@uevora.pt (M.L.C.); \\ atc@uevora.pt (A.T.C.) \\ 2 Instituto de Recursos Naturales y Agrobiologia de Sevilla (IRNAS-CSIC), 41012 Sevilla, Spain; \\ saiz@irnase.csic.es \\ 3 Departamento de Microbiología y Parasitología, Facultad de Farmacia, Universidad de Sevilla, \\ 41012 Sevilla, Spain; agarcia77@us.es \\ 4 CERENA, Instituto Superior Técnico, Universidade de Lisboa, 1049-001 Lisboa, Portugal; \\ mfcp@tecnico.ulisboa.pt \\ 5 Department of Biology and Geology, Universidad de Almeria, 04120 Almería, Spain; gsf751@ual.es (F.G.); \\ jmcalaforra@ual.es (J.M.C.) \\ 6 Department of Earth Sciences and Environmental Geology, University of Bologna, 40126 Bologna, Italy; \\ paolo.forti@unibo.it \\ 7 Instituto de Geociencias, CSIC-Universidad Complutense de Madrid, 28040 Madrid, Spain; \\ j.m.frias@igeo.ucm-csic.es \\ 8 Campus Sangolquí, Universidad de las Fuerzas Armadas (ESPE), 171103 Sangolquí, Ecuador; \\ geolecuador@gmail.com \\ 9 City U Macau Chair in Sustainable Heritage, Universidade de Évora, 7000-809 Évora, Portugal \\ 10 Departamento de Química, Universidade de Évora, Escola de Ciências e Tecnologia, \\ 7000-671 Évora, Portugal \\ * Correspondence: anamiller@uevora.pt \\ + These authors have contributed equally to this study.
}

Received: 15 October 2020; Accepted: 13 November 2020; Published: 22 November 2020

\begin{abstract}
The Galapagos Islands (Ecuador) have a unique ecosystem on Earth due to their outstanding biodiversity and geological features. This also extends to their subterranean heritage, such as volcanic caves, with plenty of secondary mineral deposits, including coralloid-type speleothems and moonmilk deposits. In this study, the bacterial communities associated with speleothems from two lava tubes of Santa Cruz Island were investigated. Field emission scanning electron microscopy (FESEM) was carried out for the morphological characterization and detection of microbial features associated with moonmilk and coralloid speleothems from Bellavista and Royal Palm Caves. Microbial cells, especially filamentous bacteria in close association with extracellular polymeric substances (EPS), were abundant in both types of speleothems. Furthermore, reticulated filaments and Actinobacteria-like cells were observed by FESEM. The analysis of $16 \mathrm{~S}$ rDNA revealed the presence of different bacterial phylotypes, many of them associated with the carbon, nitrogen, iron and sulfur cycles, and some others with pollutants. This study gives insights into subsurface microbial diversity of the Galapagos Islands and further shows the interest of the conservation of these subterranean geoheritage sites used as show caves.
\end{abstract}

Keywords: volcanic caves; reticulated filaments; bacteria; Actinobacteria; biofilms 


\section{Introduction}

The Galapagos Islands were declared Natural Heritage of Humanity by the UNESCO in 1978 due to their outstanding biodiversity and unique geological features [1]. Yet, the scientific interest on the biodiversity of Galapagos can be traced to the nineteenth-century because of its role in Charles Darwin's Theory of Evolution [2]. Regardless of the numerous studies on the fauna and flora of this volcanic archipelago [3], research focusing on microorganisms from Galapagos remains limited [4-7], particularly from the underground network of basaltic lava tubes found in many of the Galapagos Islands [8,9]. These unexplored subterranean environments are a relevant part of the archipelagos' geodiversity and comprise most of the geoheritage sites from the Islands due to their geological and geomorphological features [10,11].

Several studies have shown that complex microbial communities are found in lava tubes, particularly forming microbial mats (or biofilms) coating cave walls and secondary mineral deposits [12-16]. These biofilms are frequently found on the walls and ceilings of lava tubes, ranging from extensive coatings to small colonies. Their color includes yellow, tan, orange, grey, pink and white. These studies have revealed a highly diverse microbial biosphere, dominated by new microbial life-forms and microbial relationships different from their surface counterparts [14]. The main bacteria identified in lava tubes around the world belong to the phyla Actinobacteria, Proteobacteria, Acidobacteria, Nitrospirae, Firmicutes, Bacteroidetes and Chlorofexi [15]. Actually, Actinobacteria and Proteobacteria are the most abundant phyla in lava tubes from different parts of the world, both reaching over $50 \%$ of the total phyla identified in each cave $[12,15,17]$. Riquelme et al. [13] performed one of the largest sampling efforts in volcanic caves from Spain, Portugal, USA and Canada. The authors revealed the novelness and phylogenetic relationship of Actinobacteria in volcanic caves [13], and highlighted the importance of caves as a source of rare and novel Actinobacteria [18]. Recently, Gonzalez-Pimentel et al. [15] found abundant yellow and white-colored microbial mats coating the cave walls and secondary mineral deposits (speleothems) of lava tubes from La Palma (Canary Islands, Spain). These mats are composed of metabolically active Actinobacteria, as revealed by RNA-based analysis, mainly belonging to the order Euzebyales. Yet, the microbial diversity of lava tubes remains largely unknown, despite their interest to subsurface microbiology.

The increasing interest in speleological geoheritage, and the consequent development of speleotourism, makes urgent the design of management plans to ensure the preservation and long-term sustainability of lava tubes from the Galapagos Islands [19]. Adding to the fact that microbiological research is crucial for the preservation of Galapagos geoheritage, studies on subsurface microbiology from lava tubes are considered of extreme relevance $[12,16,18,20]$. In this study, we aimed at providing the first microbiological assessment of biofilms coating the walls of two lava tubes located in the Santa Cruz Island (Galapagos, Ecuador). The characterization of microbial communities from Galapagos lava tubes is fundamental not only to understand this uncharted microbial diversity, but also to contribute to the preservation of these unique geoheritage sites.

\section{Materials and Methods}

\subsection{Studied Site and Sampling}

The Galapagos Islands, part of the Republic of Ecuador, are an archipelago composed of 127 volcanic islands, islets and rocks situated in the eastern Pacific Ocean on the equator line. All islands of the archipelago are of volcanic origin and were formed millions of years ago [11]. The Galapagos archipelago (Figure 1A) has several active volcanos and is considered one of the most active volcanic regions of the world. Santa Cruz Island, located in the center of the archipelago, is the second-largest island with an area of $986 \mathrm{~km}^{2}$ (Figure 1B). An extensive sampling campaign was conducted in two lava tubes from Santa Cruz Island: the Royal Palm Cave (Figure 1C) and the Bellavista, also known as Gallardo Cave (Figure 1D), both hosted in basaltic lava flows of the pahoehoe type [10]. 

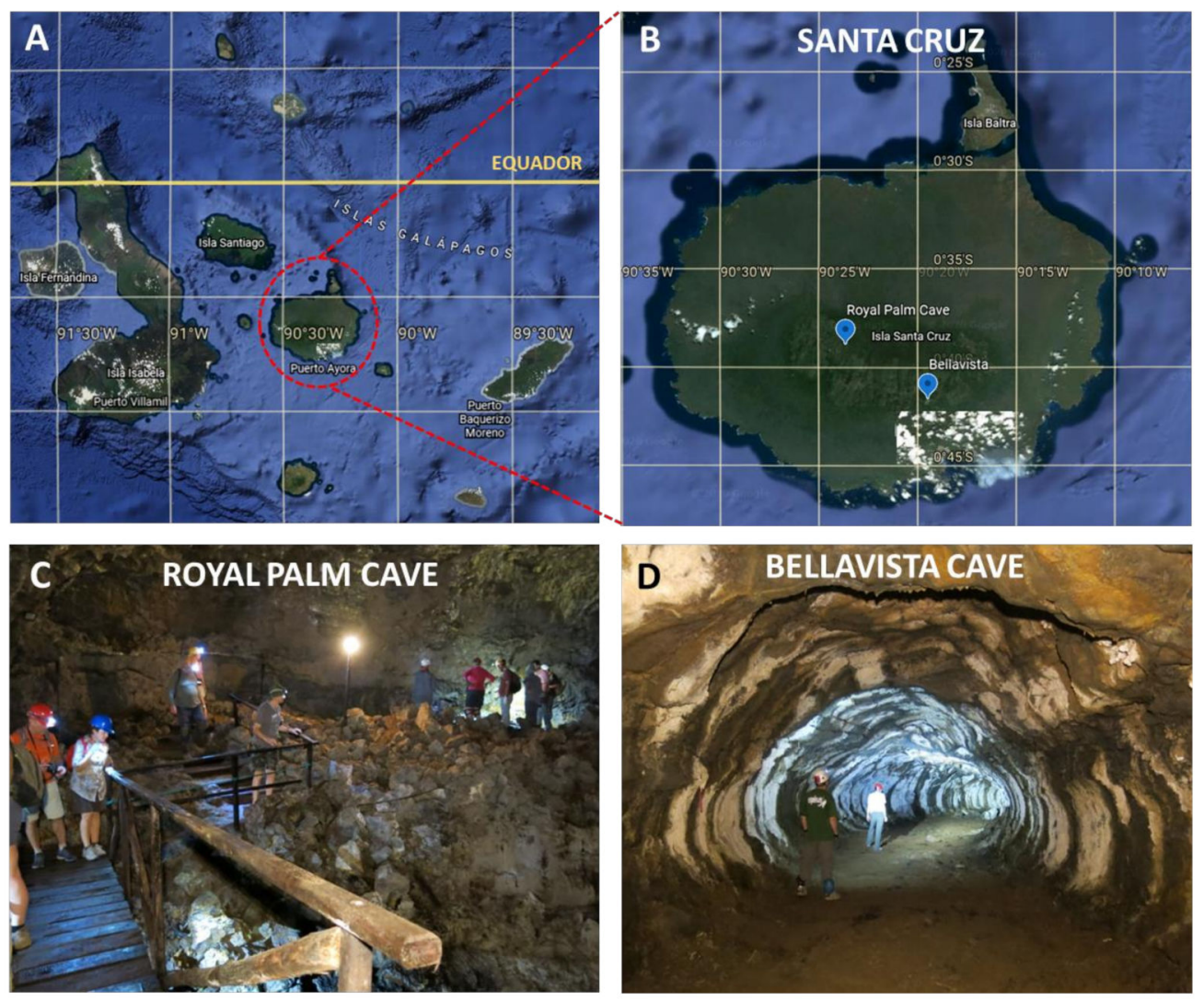

Figure 1. Location of the lava tubes: (A) Map of Galapagos Islands (Ecuador) with the location of Santa Cruz Island (red circle); (B) map of Santa Cruz Island (Galapagos, Ecuador) with the location of the lava tubes. Source: Google Maps (2020). Galapagos Islands. Retrieved from https: //goo.gl/maps/uWE17T5mHQiQKGCM6. (C) General view of Royal Palm Cave; (D) general view of Bellavista Cave (or Gallardo Cave).

Royal Palm Cave is a show cave managed by the Royal Palm Hotel for touristic use. This lava tube is $600 \mathrm{~m}$ long, $5-15 \mathrm{~m}$ in height and $2-10 \mathrm{~m}$ in width, and is located in the western part of Santa Cruz Island, near Santa Rosa Village, adjacent to the Galapagos National Park. In the Royal Palm lava tube, white patinas coating coralloid speleothems (designated Royal 2) were observed along the cavity (Figure 1C). Small fragments of the coralloids were collected from the ceiling using an ethanol-sterilized chisel and a hammer, and by gathering them into sterile $50 \mathrm{~mL}$ tubes.

Bellavista Cave, also known as "Gallardo Cave" or "Amor Tunnel" depending on the cave section, is located near Bellavista town in the eastern part of the island. The cave is the oldest and the most known show cave that was discovered in 1948 and has been open to visits since 1970 [9]. The first km of the cave is used as a tourist trail. Whitish calcite moonmilk deposits with pasty texture (designated Bella 1) were observed coating the walls of this lava tube (Figure 1D). Replicate samples of moonmilk were aseptically taken using sterile scalpels and stored in sterile $50 \mathrm{~mL}$ tubes.

All samples were stored at $4{ }^{\circ} \mathrm{C}$ until transportation to the lab and stored at $-80{ }^{\circ} \mathrm{C}$ until laboratory procedures.

\subsection{Field Emission Scanning Electron Microscopy}

Samples were examined by field emission scanning electron microscopy (FESEM) using a FESEM Jeol JSM-7001F microscope (JEOL Co. Ltd., Tokyo, Japan) on samples previously sputter coated with a thin chromium $(\mathrm{Cr})$ film, with an acceleration voltage of $15 \mathrm{kV}$. These examinations were conducted at Instituto Superior Técnico from the University of Lisbon, Portugal. 


\subsection{Molecular Analysis of Microbial Communities}

Molecular biology techniques based on 16S rRNA gene analysis were conducted for the identification of the bacterial communities associated with Bella 1 and Royal 2 speleothems. The analytical procedure was thoroughly described by Gonzalez-Pimentel et al. [15]. Briefly, DNA was extracted using the DNeasy PowerSoil Kit (Qiagen, Hilden, Germany), following the 'manufacturer's instructions. The prokaryotic $16 \mathrm{~S}$ rRNA gene was amplified by PCR using primers 27F 5'-AGAGTTTGATCMTGGCTCAG-3' [21] and 1510R 5'-GGTTACCTTGTTACGACTT-3' [21], or 907R 5' -CCCCGTCAATTCATTTGAGTTT-3' [22] for bacteria.

PCR reactions were performed in a Bio-Rad iCycler thermal cycler (Bio-Rad, Hercules, CA, USA) using the following thermal conditions: $94{ }^{\circ} \mathrm{C}$ for $2 \mathrm{~min} ; 35$ cycles of $94{ }^{\circ} \mathrm{C}$ for $20 \mathrm{~S}, 55^{\circ} \mathrm{C}$ for $20 \mathrm{~S}$, $72^{\circ} \mathrm{C}$ for $2 \mathrm{~min}$; and a final step of $72^{\circ} \mathrm{C}$ for $10 \mathrm{~min}$. Reactions were conducted in duplicate, and negative controls (containing no DNA) were included in each PCR trial. The positive PCR products were purified using the JetQuick PCR Purification Spin Kit (GenoMed Inc., Leesburg, FL, USA) according to the 'manufacturer's instructions and stored at $-20 \pm 1{ }^{\circ} \mathrm{C}$ for further analysis.

In order to obtain information of the major bacterial members, 16S rRNA gene libraries were constructed with the TOPO TA Cloning kit (Invitrogen, Carlsbad, CA, USA). Transformants were randomly picked after incubation overnight at $37 \pm 0.1{ }^{\circ} \mathrm{C}$ and transferred to multi-well plates containing Luria-Bertani (LB) medium supplemented with $100 \mu \mathrm{g} \cdot \mathrm{mL}^{-1}$ ampicillin. Afterward the plates were incubated overnight at the same temperature. Amplification of plasmids for confirming the presence of inserts was carried out using the primer pair M13/T7 (5'-CAGCAAACAGCTATGAC-3'/5'-TAATACGACTCACTATAGGG-3'). On average, 100 clones per library were sequenced by Macrogen Europe Sequencing Services (Amsterdam, The Netherlands) using universal bacterial primers.

Mothur platform was used to carry out taxonomic classification and statistical data analysis [23]. Sequences were checked for chimera using chimera.slayer implemented in mothur. Putative chimeric sequences were excluded from further analysis. After quality control, sequences were aligned and assigned to operational taxonomic units (OTUs) and defined at $97 \%$ identity. Taxonomic classification was done by comparing the sequences to the non-redundant database of the National Center for Biotechnology Information (NCBI) using the BLASTN algorithm, and the EzBioCloud database. Clone sequences were deposited in the NCBI GenBank database (http://www.ncbi.nlm.nih.gov/ genbank/) with accession numbers LT795609-LT795748 and LR760157-LR760195.

\section{Results and Discussion}

\subsection{Microscopy Observations}

White patinas were observed coating coralloid stalactites (Royal 2) from Royal Palm Cave (Figure 2A). Coralloids are irregular-shaped speleothems of small size $(<3 \mathrm{~cm})$, with botryoidal texture, resembling corals and generally composed of opal-A [24]. Coralloids from Royal Palm Cave are branched stalactites, of less than $2 \mathrm{~cm}$ in length, and are orange in color (Figure 2A).

FESEM observations of Royal 2 sample showed abundant microbial structures and extracellular polymeric substances (EPS) associated with the coralloid stalactites (Figure 3). Long reticulated filaments, resembling those reported by Melim et al. [25] and Miller et al. [16,26], were widely observed on the surface of the coralloid speleothems (Figure 3A-C). These enigmatic filaments have been frequently reported in caves worldwide, but their origin is still unknown. They comprise filamentous microorganisms with ornamented filament walls resembling a tubular reticulated mesh. Their sheaths may be mineralized, composed of calcite, Mn-oxides, silica, or copper silicates, according to the rock substrate, or of organic composition, as reported by Melim et al. [27]. Abundant actinobacterial-like cells were also observed on the surface of the coralloids, representing the most common fraction of the microbial components on the coralloid deposits found in the Royal Palm lava tube (Figure 3D). They comprise clusters of coccoid-shaped cells with spiny surface ornamentation. Colored microbial 
mats or biofilms composed of Actinobacteria are frequently found in lava tubes all over the world [28]. These biofilms or microbial mats are composed of microbial cells embedded in a slimy matrix of EPS that allow the attachment of the cells to solid surfaces and thus the development of small colonies or extensive colored mats on the walls and speleothems of caves, as observed in Galapagos lava tubes (Figure 1D).
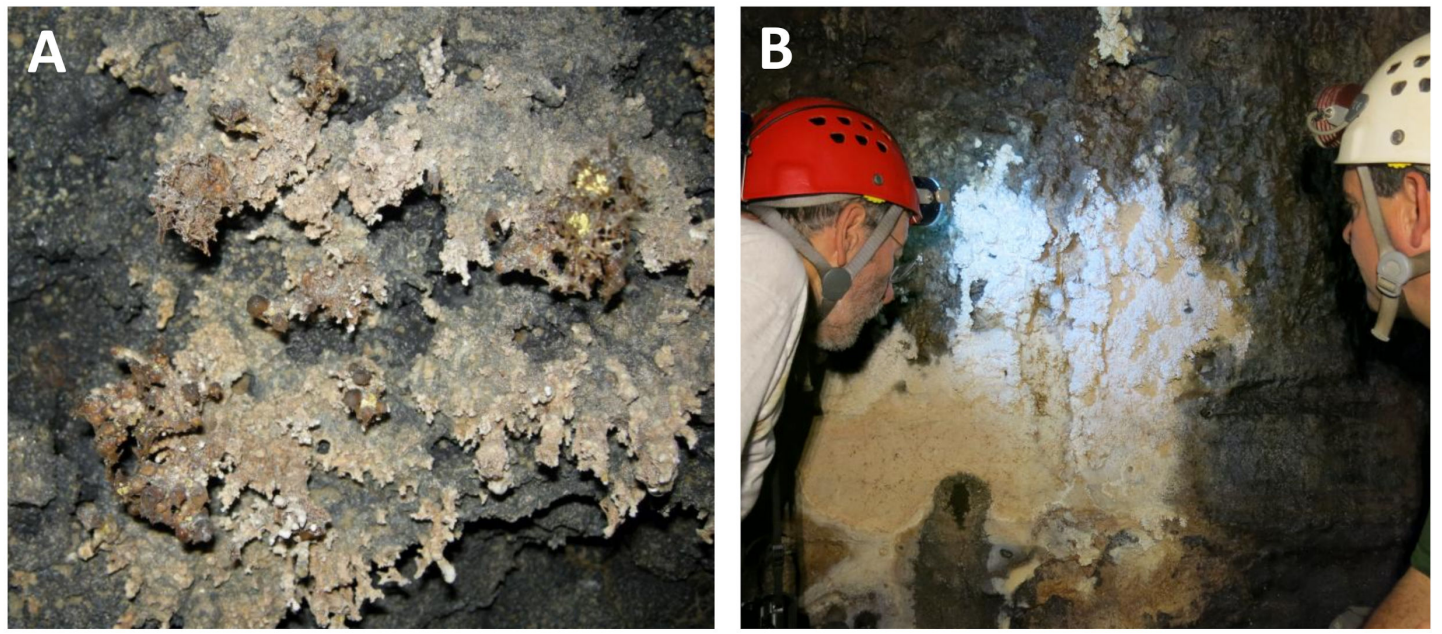

Figure 2. Field images of the speleothems collected in the lava tubes from Santa Cruz Island (Galapagos, Ecuador): (A) Coralloid stalactites with whitish coatings (Royal 2) from Royal Palm Cave; (B) white moonmilk coating the walls of Bellavista Cave.
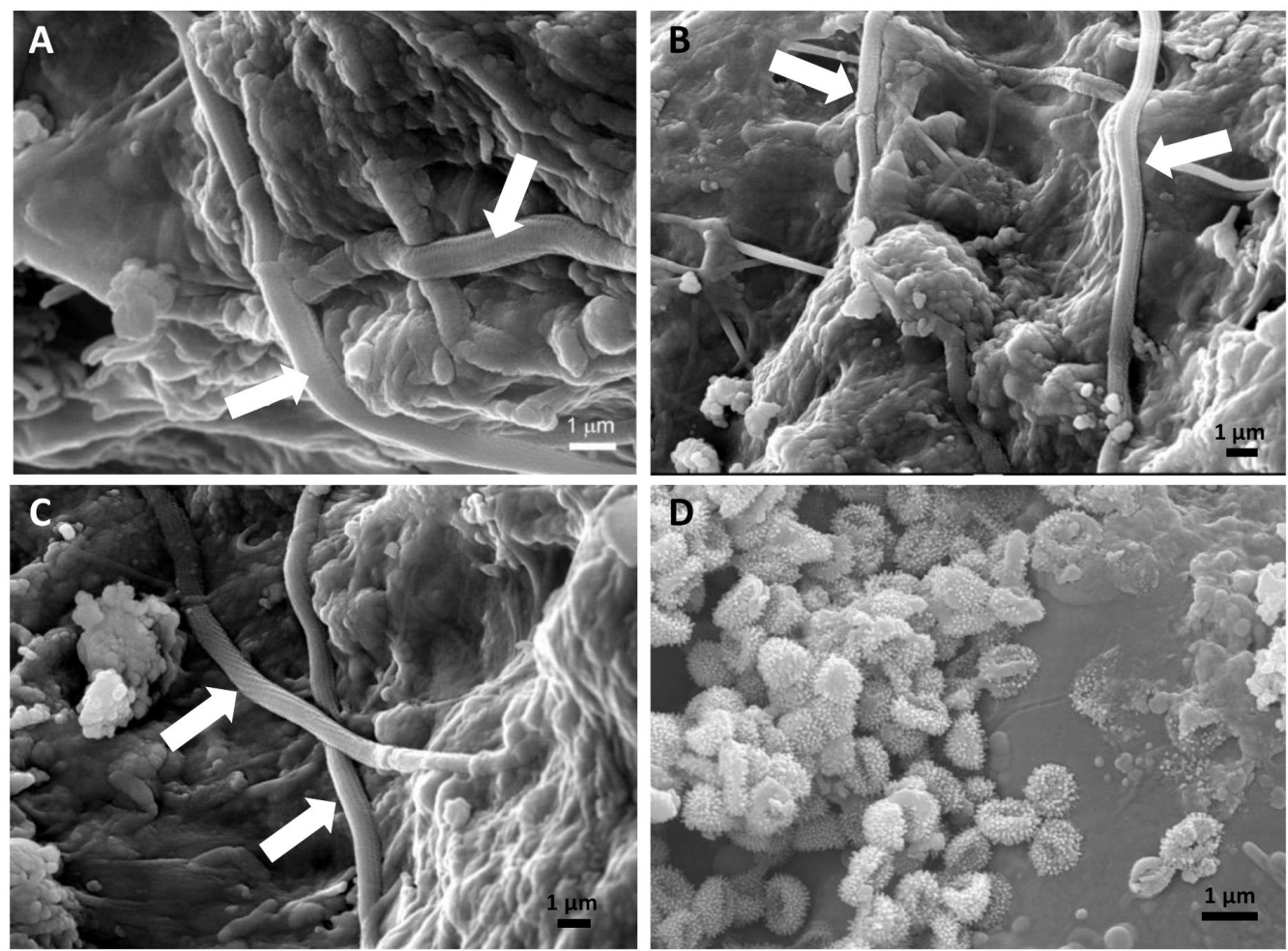

Figure 3. Field emission scanning electron microscopy (FESEM) images of coralloid stalactites (Royal 2) from Royal Palm Cave, showing: (A-C) Reticulated filaments embedded in a matrix of extracellular polymeric substances (EPS). (D) Clusters of Actinobacteria-like cells with spiny ornamentation. White arrows show reticulated filaments. Magnifications for (A-D) are 9000, 5500, 6500 and 10,000, respectively. 
Moonmilk deposits (Bella 1) were observed coating extensive areas of the walls of Bellavista Cave in Santa Cruz Island (Figure 2B). Under FESEM, these white pasty-like coatings showed the characteristic needle-shaped calcite fibers of moonmilk intimately associated with microbial cells (Figure 4), and frequently reported in caves [29,30]. Moonmilk are soft, wet, pasty or cotton-like deposits formed on walls, ceilings or cave floors, and are generally composed of needle-shaped calcite [24,29]. These whitish deposits have been found to be associated with microbial cells and EPS, leading some authors to hypothesize that moonmilk is produced by the activity of bacteria [24,29]. Miller et al. [29] found that most of the bacterial clones retrieved from calcite moonmilk in a granite spring water tunnel in Porto (Portugal) were affiliated to Actinobacteria and Proteobacteria. Maciejewska et al. [31] showed that Proteobacteria (ranging from 30\% to 52\%), followed by Actinobacteria (ranging from 9\% to 23\%) were the most abundant phyla in moonmilk samples from a limestone cave in Belgium. Nevertheless, the origin of moonmilk is still a controversial issue. Moonmilk fibers from Bellavista Cave were found embedded in a slime matrix of EPS and coccoid-like microbial cells with smooth surfaces (Figure 4A,B). In addition, spores of Actinobacteria-like cells with spiny surface ornamentation were also observed to be associated with the needle-shaped calcite fibers (Figure 4C,D).
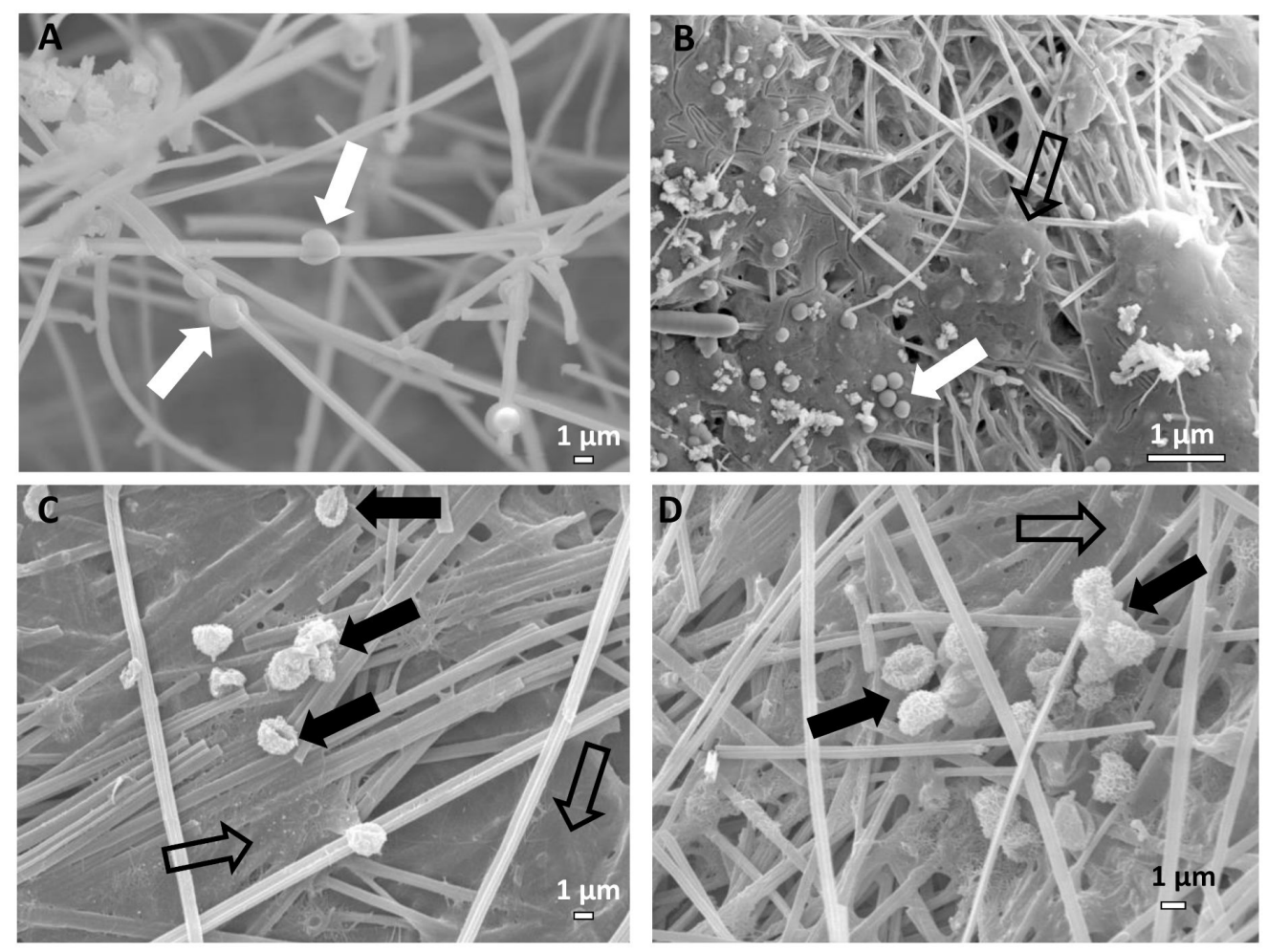

Figure 4. Field emission scanning electron microscopy (FESEM) images of moonmilk sample (Bella 1) from Bellavista Cave, depicting: (A,B) Needle-shape calcite fibers with coccoid-like microbial cells with smooth surfaces; (C,D) Actinobacteria-like cells with spiny surface ornamentation associated with moonmilk. Open arrows show EPS. White arrows indicate coccoid-shaped cells with smooth surfaces. Black arrows show Actinobacteria-like cells. Black open arrows show the matrix of EPS. Magnifications for (A-D) are 3000, 1500, 4500 and 4500, respectively.

\subsection{Microbial Communities}

A total of 223 chimera-free sequences were obtained from the analyzed speleothems from Santa Cruz lava tubes. Independent libraries of DNA sequences from each sample were built, with the objective of detecting the total bacteria present in these samples. The distribution of the different phyla in moonmilk (Bella 1) and coralloid (Royal 2) samples is shown in Figure 5. The phyla Acidobacteria $(21 \%)$ and Gemmatimonadetes (21\%) were the most abundant in Bella 1. Other taxonomic groups 
with significant representation in Bella 1 were Actinobacteria (14\%), Firmicutes $(8 \%)$ and Proteobacteria (7\%). Royal 2 was mainly dominated by Actinobacteria (34\%) and Proteobacteria $(26 \%)$ followed by Gemmatimonadetes (21\%). Firmicutes (8\%), Acidobacteria (3\%) and Chloroflexi $(3 \%)$ were relatively abundant in Royal 2 . The few other phyla in both samples were around $1 \%$ in relative abundance.
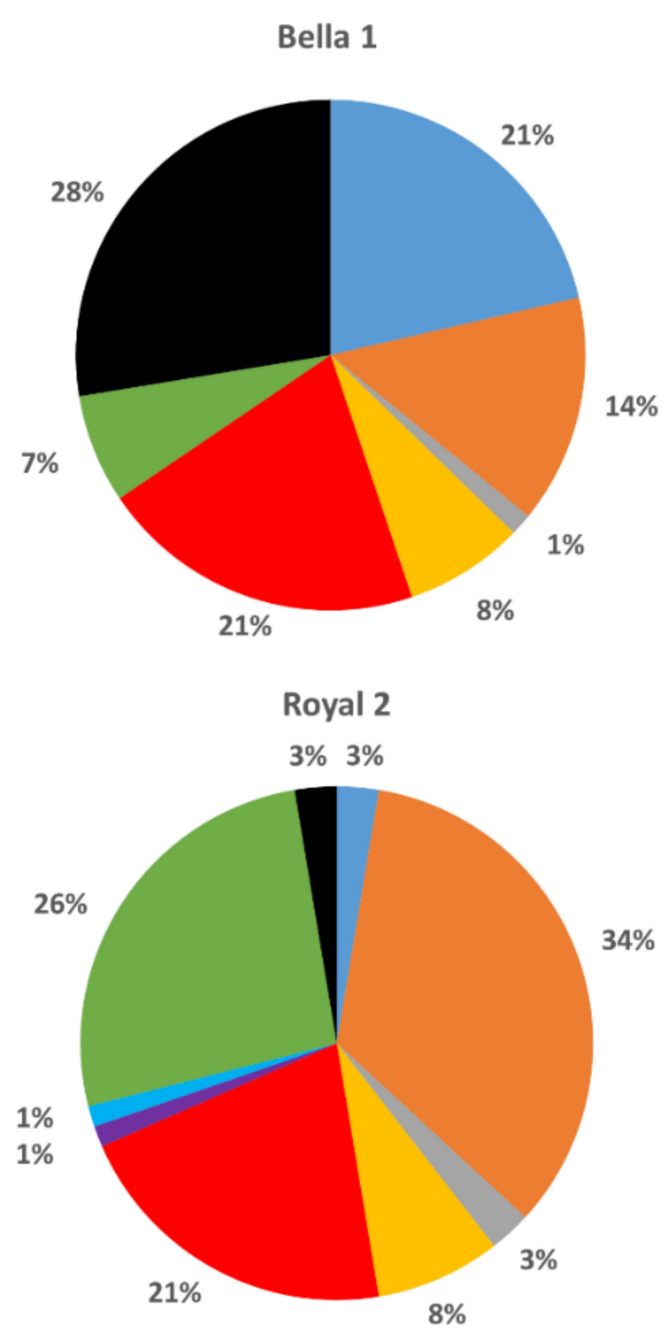

\section{- Acidobacteria}

Actinobacteria

Chloroflexi

Firmicutes

- Gemmatimonadetes

- Nitrospirae

- Planctomycetes

Proteobacteria

- Unclassified

Figure 5. Distribution of bacterial phyla retrieved from Bella 1 and Royal 2 samples.

The phylogenetic affiliations of the 223 sequences obtained from the lava tube samples from the Galapagos lava tubes are listed in Tables S1 and S2. The sequences were distributed in 93 OTUs for Bella 1 (Table S1) and 70 OTUs for Royal 2 (Table S2). Royal 2 showed the highest bacterial diversity, with a wider variety of OTUs showing $>90 \%$ similarity with the closest bacterial isolate (26 OTUs, 37\%), in comparison with Bella 1 (solely 16 OTUs, 17\%). The rest of the sequences could only be assigned to families or orders in the EZBiocloud database (ChunLab, Inc., Seocho-gu, Seoul, South Korea), as established by Yarza et al. [32] for taxonomic thresholds (Supplementary Tables S1 and S2). The differences and abundance in phyla and species identified showed that the microbial communities from both samples were dissimilar, which is in fair agreement with the different mineralogical composition (please see Section 3.2).

Comparing the microbial community structure in Royal 2 and Bella 1 showed that most of the phylotypes from the moonmilk deposits (Bella 1) had similarity of $<90 \%$ with their closest isolates, indicating that distinct speleothems from a cave may host different populations, including unique and rare bacteria. Maciejewska et al. [31] studying three different moonmilk deposits from Grotte des Collemboles Cave (Belgium) showed that $34 \%$ were exclusive to one deposit, resulting in the 
isolation of novel Actinobacteria. Of note is the fact that $28 \%$ of sequences in the moonmilk (Bella 1) were unclassified, with most of the OTUs unlinked to culturable bacteria. In the coralloid (Royal 2) sample, the percentage of unclassified bacteria solely reached 3\%. Unclassified bacteria from Bella 1 and Royal 2 showed percentages of similarity of less than 80\% with sequences from EZBiocloud database; therefore, the closest isolated strains were not indicated in Tables S1 and S2, but only the nearest uncultured homologue from the NCBI database. The presence of a large number of clones with similarities lower than $80 \%$ with cultivated bacteria in Bella 1 suggests that this lava tube has a great potential for the isolation of novel species. Carvajal Barriga et al. [4] could not find proof of endemism in Galapagos yeasts, but Dal Forno et al. [5] reported a high level of endemism among Galapagos lichens. The question is whether this can also be extensive to bacteria.

Regarding the study of the most abundant phyla and classes in the two samples from Santa Cruz Island lava tubes, the phylum Acidobacteria was represented in Bella 1 by sequences included in the family Vicinamibacteraceae, recently described by Huber and Overmann [33] to accommodate the subdivision 6 of Acidobacteria (the closest cultivated relatives were Luteitalea and Vicinamibacter). These two taxa were also retrieved in Royal 2, but at lower abundances. The family Vicinimibacteraceae is one of the most abundant actinobacterial groups in soils [34] and caves [35,36]. Sequences affiliated to Luteitalea and Vicinamibacter were also retrieved from lava tubes from the volcanic La Palma Island, Spain [37].

Gemmatimonadetes were also well represented in Bella 1, with members assigned to the family Gemmatimonadaceae and represented by Gemmatimonas and Roseisolibacter genera. Both phylotypes were also found in Royal 2. Gemmatimonadetes bacteria have a cosmopolitan distribution in terrestrial systems, including soils [38] and subsurface environments [39,40].

In Bella 1, the phylum Actinobacteria was composed of sequences affiliated to the order Thermoleophilales (Thermoleophilum), and the families Iamiaceae (Aquihabitans), Gaiellaceae (Gaiella), and Frankiaceae (Frankia). Pseudarthrobacter sulfinivorans was identified at the species level. In Royal 2, sequences from Iamiaceae (Aquihabitans and Iamia) and Gaiellaceae (Gaiella) were also retrieved, as well as other families: Pseudonocardiaceae (Pseudonocardia), Euzebyaceae (Euzebya) and the orders Acidimicrobiales (Aciditerrimonas) and Actinomycetales (Streptomyces).

Actinobacteria and Proteobacteria are the two most dominant phyla in caves [31,41], and a large number of actinobacterial genera were retrieved in different caves, either as isolates, clones or Next Generation Sequencing (NGS) studies. Interestingly, most of the genera and families reported in this study were also found by Gonzalez-Pimentel et al. [15] and Gonzalez-Pimentel [37] in different lava tubes from La Palma Island.

In Bella 1, within the phylum Firmicutes, the species Bacillus mycoides and sequences of the orders Bacillales (Calditerricola) and Thermoanaerobacteriales (Thermanaeromonas) were identified. In the coralloid speleothems (Royal 2), the species Paenibacillus selenitireducens and Ammoniphilus resinae were identified, as well as sequences affiliated to the orders Thermosediminibacterales (Thermosediminibacter), Thermoanaerobacteriales (Thermodesulfitimonas), and to the family Syntrophomonadaceae (Dethiobacter). Both aerobic and anaerobic members of Firmicutes are common in caves, although Bacillus dominates $[42,43]$.

In Royal 2, within the class Alphaproteobacteria, the species Methylocapsa palsarum, Ensifer adhaerens, Hyphomicrobium zavarzinii, Phenylobacterium haematophilum, and Methyloceanibacter marginalis were noticeable. Other sequences were affiliated to the families Sphingomonadaceae (Sphingosinicella) and Hyphomicrobiaceae (Filomicrobium). All these species, except Sphingosinicella, were found in lava tubes of La Palma Island [37].

Because most of the detected phylotypes showed values of similarity lower than $90 \%$ with cultivated species, the phylogenetic similarities were uncertain and, therefore, it was difficult to conduct the assignment of functional capabilities for a number of retrieved sequences. This problem has been previously raised in microbiological studies in lava tubes $[44,45]$. However, it is worth 
mentioning the possible metabolic roles of the identified bacterial species in the lava tubes. These species can be grouped in three categories:

(i) Methanotrophs/methylotrophs

Pseudarthrobacter sulfonivorans is a facultative methylotroph involved in dimethylsulfone metabolism [46,47] and can degrade aromatic compounds [48].

Methyloceanibacter superfactus and Methyloceanibacter marginalis were isolated from marine surface sediments [45]. Both species grow aerobically on methanol and were able to use, as alternative carbon sources, ethanol, formate and dimethylcarbonate, and ammonium and nitrate as inorganic nitrogen sources. These two bacteria were also present in lava tubes from La Palma [37].

Methylocapsa palsarum is an aerobic, obligate methanotroph which is capable of atmospheric nitrogen fixation under reduced oxygen tension [49]. Several studies report on the abundance of cave methanotrophic communities [50,51].

Hyphomicrobium zavarzinii is a bacterium that was found in a lava tube from La Palma [37]. Hyphomicrobium spp. are restricted facultative methylotrophs with denitrification capacities [52]. In addition, members of the genera Hyphomicrobium are known to be involved in manganese oxidation and precipitation in caves [53].

\section{(ii) Predatory bacteria}

Lysobacter terricola. Lysobacter species are widely distributed in soils and caves and have a lytic effect on other microorganisms due to their extracellular enzymes including chitinases, glucanases and peptidases [54]. Ensifer adhaerens has also predation activity against other bacteria. This species can be found in caves [55] and can induce calcium carbonate precipitation [56]. Predation of phototrophic biofilms by species of Lysobacter has been reported for Nerja Cave in Spain [43].

(iii) Plant/soil bacteria

Mesorhizobium amorphae and Mesorhizobium silamurunense were found in root nodules from leguminous plants [57]. Usually roots can be observed in the ceiling of lava tubes close to the surface; water flowing through cracks or along the roots can transport plant materials and bacteria into the cave. Mesorhizobium amorphae was isolated from a Roman tomb in Spain and M. silamurunense was found among the sequences retrieved from the same tomb [58].

Paenibacillus selenitireducens was isolated from a selenium mine [59]. Volcanic rocks (basalts, phonolites) contain selenium [60] which could explain the presence of this species in Santa Cruz Island lava tubes.

Ammoniphilus resinae was isolated from a resin fragment collected in a tropical forest, and contrarily to the other two species of Ammoniphilus, which requires high concentrations of ammonium ions for growth, in A. resinae growth does not occur in ammonium-based medium [61]. No other data are available on this bacterium.

Bacillus mycoides is a ubiquitous soil microorganism that is frequently found in caves $[62,63]$ and also in La Palma lava tubes [15].

The pathogenic Ralstonia pickettii was an abundant bacterium in the heavily polluted and anthropized Lascaux Cave, as a result of years of benzalkonium chloride treatments to eliminate a fungal outbreak [64]. Shigella sonnei, a human pathogen, was also found in this French cave as well as in the Spanish Ardales Cave [65]. This bacterium seems to be common in Galapagos Island and has been found in fecal samples from finches [66].

Advenella kashmirensis is a facultatively sulfur-chemolithoautotrophic bacterium that uses thiosulfate or tetrathionate as an electron and energy source [67]. This bacterium has been found in polluted environments where it degrades polycyclic aromatic hydrocarbons. Seven genes were identified as being involved in hydrocarbon degradation [68]. 
Phenylobacterium haematophilum: The genus Phenylobacterium is composed of 13 species mostly isolated from terrestrial and aquatic environments that can use a wide range of organic compounds as a carbon and energy sources. A strain of $P$. haematophilum was capable of metabolizing pollutant linear alkylbenzene sulfonates [69].

Other metabolic traits for the lava tube bacteria can be deduced from the study of the taxonomic groups to which the most abundant sequences recovered from the two speleothem samples belong. The members of the family Vicinimibacteraceae grow chemoorganotrophically utilizing a broad range of substrates including different sugars, organic acids, nucleic acids and complex proteinaceous compounds $[70,71]$. This family dominates in soils with a neutral or slightly basic $\mathrm{pH}$, due to a more efficient enzymatic system for utilizing complex biopolymers and thus outcompeting with copiotrophs [72]. In addition, the genome of Luteitalea pratensis harbours genes encoding for a dissimilatory nitrite reductase ( $n r f H A)$ that catalyses the reduction of nitrite to ammonia [73].

A high number of the representative sequences of Actinobacteria were assigned to the order Thermoleophilales, which contains only the family Thermoleophilaceae and a single genus: Thermoleophilum [74]. The genus was described for an aerobic, obligately thermophilic bacterium restricted to growth on a narrow range of $n$-alkanes. The two species of Thermoleophilum, T. album and T. minutum, grow solely with $n$-alkanes from 13 to 20 carbons in length at temperatures from 45 to $70{ }^{\circ} \mathrm{C}$ [75]. However, several strains were isolated from non-thermal areas such as soils [76], which could explain their presence in the lava tubes.

The actinobacterial family Iamiaceae embraces the genera Aquihabitans and Iamia, among others. Sequences matching with both genera are retrieved from terrestrial and aquatic environments [77-79]. Aquihabitans was also found in anaerobic digesters [80] and reported to be a denitrifying bacterium [79]. Iamia formed part of the microbial community of a soil polluted with both $n$-alkanes and polycyclic aromatic hydrocarbons after bioremediation [81]. The actinobacterial order Acidimicrobiales (which includes the Fe-reducer Aciditerrimonas) was present in anaerobic digesters [80], and soils [82-84]. Finally, Gaiellaceae (Gaiella) was found in limestone [40,85] and volcanic caves [13,37]. For Zhang et al. [86] Gaiella is involved in the N cycle.

Gemmatimonadetes (Gemmatimonas) metabolizes an array of organic substrates, including a broad range of sugars, amino acids, and polymer [87]. Wang et al. [38] suggested that the Gemmatimonadetes are involved in organic carbon metabolism and the cycling of major elements in soil. A high proportion of Gemmatimonadetes was found in arid soils; this suggests an adaption to low-moisture environments [39].

To summarize, the survey of taxonomic groups constituting the microbial communities of Santa Cruz lava tubes reveals the abundant presence of phylotypes previously detected in other lava tubes and includes methanotrophs/methylotrophs, soil and plant bacteria, and microorganisms involved in the degradation of pollutants. These data evidence that the conservation of these unique geosites, from a microbiological point of view, is an important issue, particularly when used as show caves.

\section{Conclusions}

To fully understand the microbial diversity of moonmilk and coralloid speleothems from lava tubes of the Galapagos Islands, we conducted for the first time a comprehensive microscopy and molecular biology investigation.

Microbiological analysis showed the typical microbial features of volcanic environments and a remarkable similarity with those from La Palma lava tubes, suggesting that the volcanic rocks select for specific groups of microorganisms.

The analysis of $16 \mathrm{~S}$ rDNA revealed the presence of different bacterial phylotypes, many of them associated with the carbon, nitrogen, iron and sulfur cycles, and some others involved in the degradation of pollutants. This latter is relevant due to the use of the lava tubes as show caves.

The presence of a large number of unclassified bacteria in Bella 1 suggests that this lava tube has a great potential for the isolation of novel species. Further research is needed to ascertain the possible presence of novel (likely endemic) bacteria in caves from the Galapagos Islands. 
Supplementary Materials: The following are available online at http://www.mdpi.com/2079-6412/10/11/1134/s1, Table S1: Phylogenetic affiliations of the 16S rRNA gene sequences of total bacteria obtained from Bella 1 sample (145 sequences, 93 OTUs), Table S2: Phylogenetic affiliations of the 16S rRNA gene sequences of total bacteria obtained from Royal 2 sample (76 sequences, 70 OTUs).

Author Contributions: Conceptualization, A.Z.M., J.M.C. and P.F.; Data curation, A.Z.M., A.M.G.-S., M.L.C. and M.F.C.P.; Formal analysis, F.G.; Funding acquisition, J.M.C. and T.T.; Investigation, A.Z.M., M.L.C., M.F.C.P., F.G., J.M.C., P.F., J.M.-F., T.T., A.T.C. and C.S.-J.; Methodology, A.Z.M.; Resources, A.Z.M. and A.T.C.; Writing-original draft, A.Z.M., A.M.G.-S. and C.S.-J.; Writing—review and editing, A.Z.M., M.L.C., M.F.C.P., F.G., P.F., J.M.-F., T.T., A.T.C. and C.S.-J. All authors have read and agreed to the published version of the manuscript.

Funding: This research was funded by the Ecuadorian Ministry of Environment (Project PC-65-14 National Park Galapagos), by the Spanish project MINECO CGL2016-75590-P with European Regional Development Fund and the Portuguese Foundation for Science and Technology (Fundação para a Ciência e a Tecnologia-FCT) under the project UID/Multi/04449/2019 for HERCULES/UE. AMGS was supported by a FPU fellowship of the Spanish Ministry of Education, Culture and Sport (AP2010-2052). AZM was supported by a Marie Curie Intra-European Fellowship of the European Commission's 7th Framework Programme (PIEF-GA-2012-328689-DECAVE) and a CEECIND/01147/2017 contract from FCT. MLC was supported by a CEECIND/00349/2017 contract from FCT. FG was financially supported by the "HIPATIA" research program of the University of Almeria.

Conflicts of Interest: The authors declare no conflict of interest.

\section{References}

1. Galápagos Islands-UNESCO World Heritage Centre. Available online: https://whc.unesco.org/en/list/1/ (accessed on 15 October 2020).

2. Satre, D. Using the Ultimate Natural Laboratory to Teach Evolution, Natural Selection and Biodiversity. Procedia Soc. Behav. Sci. 2015, 177, 289-294. [CrossRef]

3. Elias, S.A. Galápagos Island Biodiversity. In Encyclopedia of the World's Biomes; Elsevier: Amsterdam, The Netherlands, 2020; pp. 198-216.

4. Carvajal Barriga, E.J.; Barahona, P.P.; Tufiño, C.; Bastidas, B.; Guamán-Burneo, C.; Freitas, L.; Rosa, C. An Overview of the Yeast Biodiversity in the Galápagos Islands and Other Ecuadorian Regions. In Biodiversity -The Dynamic Balance of the Planet; InTech: London, UK, 2014.

5. Dal Forno, M.; Bungartz, F.; Yánez-Ayabaca, A.; Lücking, R.; Lawrey, J.D. High levels of endemism among Galapagos basidiolichens. Fungal Divers. 2017, 85, 45-73. [CrossRef]

6. Mayhew, L.E.; Geist, D.J.; Childers, S.; Pierson, J. Microbial community comparisons as a function of the physical and geochemical conditions of Galápagos Island fumaroles. Geomicrobiol. J. 2007, 24, 615-625. [CrossRef]

7. Campoverde, N.C.G.; Hassenrück, C.; Buttigieg, P.L.; Gärdes, A.; Carolina, N.; Campoverde, G.; Buttigieg, P.L.; Gärdes, A. Characterization of bacterioplankton communities and quantification of organic carbon pools off the Galapagos Archipelago under contrasting environmental conditions. PeerJ 2018, 2018. [CrossRef] [PubMed]

8. Taylor, S.J.; Addison, A.; Toulkeridis, T. Biological potential of under-studied cave fauna of the Galapagos Islands. Rev. Geoespacial 2011, 8, 13-22.

9. Constantin, S.; Toulkeridis, T.; Moldovan, O.T.; Villacís, M.; Addison, A. Caves and karst of Ecuador-state-of-the-art and research perspectives. Phys. Geogr. 2019, 40, 28-51. [CrossRef]

10. Gallardo, G.; Toulkeridis, T. Volcanic Caves and Other Speleological Attractions. Santa Cruz, Galápagos; San Francisco University Press: San Francisco, CA, USA, 2008.

11. Simkin, T. Geology of Galapagos. Biol. J. Linn. Soc. 1984, 21, 61-75. [CrossRef]

12. Northup, D.E.; Melim, L.A.; Spilde, M.N.; Hathaway, J.J.M.; Garcia, M.G.; Moya, M.; Stone, F.D.; Boston, P.J.; Dapkevicius, M.L.N.E.; Riquelme, C. Lava cave microbial communities within mats and secondary mineral deposits: Implications for life detection on other planets. Astrobiology 2011, 11, 601-618. [CrossRef]

13. Riquelme, C.; Hathaway, J.J.M.; Dapkevicius, M.L.N.E.; Miller, A.Z.; Kooser, A.; Northup, D.E.; Jurado, V.; Fernandez, O.; Saiz-Jimenez, C.; Cheeptham, N. Actinobacterial diversity in volcanic caves and associated geomicrobiological interactions. Front. Microbiol. 2015, 6. [CrossRef]

14. Lavoie, K.H.; Winter, A.S.; Read, K.J.H.; Hughes, E.M.; Spilde, M.N.; Northup, D.E. Comparison of bacterial communities from lava cave microbial mats to overlying surface soils from Lava Beds National Monument, USA. PLoS ONE 2017, 12, e0169339. [CrossRef] 
15. Gonzalez-Pimentel, J.L.; Miller, A.Z.; Jurado, V.; Laiz, L.; Pereira, M.F.C.; Saiz-Jimenez, C. Yellow coloured mats from lava tubes of La Palma (Canary Islands, Spain) are dominated by metabolically active Actinobacteria. Sci. Rep. 2018, 8. [CrossRef] [PubMed]

16. Miller, A.Z.; Pereira, M.F.C.; Calaforra, J.M.; Forti, P.; Dionísio, A.; Saiz-Jimenez, C. Siliceous Speleothems and Associated Microbe-Mineral Interactions from Ana Heva Lava Tube in Easter Island (Chile). Geomicrobiol. J. 2014, 31, 236-245. [CrossRef]

17. Hathaway, J.J.M.; Garcia, M.G.; Balasch, M.M.; Spilde, M.N.; Stone, F.D.; Dapkevicius, M.D.L.N.E.; Amorim, I.R.; Gabriel, R.; Borges, P.A.V.; Northup, D.E. Comparison of Bacterial Diversity in Azorean and Hawai'ian Lava Cave Microbial Mats. Geomicrobiol. J. 2014, 31, 205-220. [CrossRef] [PubMed]

18. Riquelme, C.; de Dapkevicius, M.L.E.; Miller, A.Z.; Charlop-Powers, Z.; Brady, S.; Mason, C.; Cheeptham, N. Biotechnological potential of Actinobacteria from Canadian and Azorean volcanic caves. Appl. Microbiol. Biotechnol. 2017, 101, 843-857. [CrossRef] [PubMed]

19. Antić, A.; Peppoloni, S.; Di Capua, G. Applying the Values of Geoethics for Sustainable Speleotourism Development. Geoheritage 2020, 12, 1-9. [CrossRef]

20. Léveillé, R.J.; Datta, S. Lava tubes and basaltic caves as astrobiological targets on Earth and Mars: A review. Planet. Space Sci. 2010, 58, 592-598. [CrossRef]

21. Lane, D. 16S/23S rRNA sequencing. In Nucleic Acid Techniques in Bacterial Systematic; Stackenbrandt, E., Goodfellow, M., Eds.; John Wiley: Chichester, UK, 1991; pp. 115-175.

22. Weisburg, W.G.; Barns, S.M.; Pelletier, D.A.; Lane, D.J. $16 \mathrm{~S}$ ribosomal DNA amplification for phylogenetic study. J. Bacteriol. 1991, 173, 697-703. [CrossRef]

23. Schloss, P.D.; Westcott, S.L.; Ryabin, T.; Hall, J.R.; Hartmann, M.; Hollister, E.B.; Lesniewski, R.A.; Oakley, B.B.; Parks, D.H.; Robinson, C.J.; et al. Introducing mothur: Open-source, platform-independent, community-supported software for describing and comparing microbial communities. Appl. Environ. Microbiol. 2009, 75, 7537-7541. [CrossRef]

24. Hill, C.; Forti, P. Cave Minerals of the World; National Speleological Society: Huntsville, Al, USA, 1997; ISBN 1-879961-07-5.

25. Melim, L.A.; Northup, D.E.; Spilde, M.N.; Jones, B.; Boston, P.J.; Bixby, R.J. Reticulated filaments in cave pool speleothems: Microbe or mineral? J. Cave Karst Stud. 2008, 70, 135-141. [CrossRef]

26. Miller, A.Z.; Hernández-Mariné, M.; Jurado, V.; Dionísio, A.; Barquinha, P.; Fortunato, E.; Afonso, M.J.; Chaminé, H.I.; Saiz-Jimenez, C. Enigmatic reticulated filaments in subsurface granite. Environ. Microbiol. Rep. 2012, 4, 596-603. [CrossRef]

27. Melim, L.A.; Northup, D.E.; Spilde, M.N.; Boston, P.J. Update: Living reticulated filaments from Herbstlabyrinth-Adventhöhle Cave System, Germany. J. Cave Karst Stud. 2015, 77, 87-90. [CrossRef]

28. Riquelme, C.; Rigal, F.; Hathaway, J.J.; Northup, D.E.; Spilde, M.N.; Borges, P.A.V.; Gabriel, R.; Amorim, I.R.; Dapkevicius, M.L.N.E. Cave microbial community composition in oceanic islands: Disentangling the effect of different colored mats in diversity patterns of Azorean lava caves. FEMS Microbiol. Ecol. 2015, 91, fiv141. [CrossRef] [PubMed]

29. Miller, A.Z.; Garcia-Sanchez, A.M.; Martin-Sanchez, P.M.; Pereira, M.F.C.; Spangenberg, J.E.; Jurado, V.; Dionísio, A.; Afonso, M.J.; Iglésias Chaminé, H.I.; Hermosin, B.; et al. Origin of abundant moonmilk deposits in a subsurface granitic environment. Sedimentology 2018, 65. [CrossRef]

30. Cañaveras, J.C.; Cuezva, S.; Sanchez-Moral, S.; Lario, J.; Laiz, L.; Gonzalez, J.M.; Saiz-Jimenez, C. On the origin of fiber calcite crystals in moonmilk deposits. Naturwissenschaften 2006, 93, 27-32. [CrossRef] [PubMed]

31. Maciejewska, M.; Całusińska, M.; Cornet, L.; Adam, D.; Pessi, I.S.; Malchair, S.; Delfosse, P.; Baurain, D.; Barton, H.A.; Carnol, M.; et al. High-throughput sequencing analysis of the actinobacterial spatial diversity in moonmilk deposits. Antibiotics 2018, 7, 27. [CrossRef]

32. Yarza, P.; Yilmaz, P.; Pruesse, E.; Glöckner, F.O.; Ludwig, W.; Schleifer, K.H.; Whitman, W.B.; Euzéby, J.; Amann, R.; Rosselló-Móra, R. Uniting the classification of cultured and uncultured bacteria and archaea using $16 \mathrm{~S}$ rRNA gene sequences. Nat. Rev. Microbiol. 2014, 12, 635-645. [CrossRef]

33. Huber, K.J.; Overmann, J. Vicinamibacteraceae fam. Nov., the first described family within the subdivision 6 Acidobacteria. Int. J. Syst. Evol. Microbiol. 2018, 68, 2331-2334. [CrossRef]

34. Jones, R.T.; Robeson, M.S.; Lauber, C.L.; Hamady, M.; Knight, R.; Fierer, N. A comprehensive survey of soil acidobacterial diversity using pyrosequencing and clone library analyses. ISME J. 2009, 3, 442-453. [CrossRef] 
35. Schabereiter-Gurtner, C.; Saiz-Jimenez, C.; Piñar, G.; Lubitz, W.; Rölleke, S. Altamira cave Paleolithic paintings harbor partly unknown bacterial communities. FEMS Microbiol. Lett. 2002, 211, 7-11. [CrossRef]

36. Zimmermann, J.; Gonzalez, J.M.; Saiz-Jimenez, C.; Ludwig, W. Detection and phylogenetic relationships of highly diverse uncultured acidobacterial communities in Altamira Cave using 23S rRNA sequence analyses. Geomicrobiol. J. 2005, 22, 379-388. [CrossRef]

37. González Pimentel, J.L. Microorganismos de las Cuevas Volcánicas de La Palma (Islas Canarias). Diversidad y Potencial uso Biotecnológico. Ph.D. Thesis, Universidad Pablo de Olavide, Sevilla, Spain, 2019.

38. Wang, J.; Wang, J.; Zhang, Z.; Li, Z.; Zhang, Z.; Zhao, D.; Wang, L.; Lu, F.; Li, Y. Shifts in the Bacterial Population and Ecosystem Functions in Response to Vegetation in the Yellow River Delta Wetlands. mSystems 2020, 5. [CrossRef]

39. DeBruyn, J.M.; Nixon, L.T.; Fawaz, M.N.; Johnson, A.M.; Radosevich, M. Global biogeography and quantitative seasonal dynamics of Gemmatimonadetes in soil. Appl. Environ. Microbiol. 2011, 77, 6295-6300. [CrossRef] [PubMed]

40. Yun, Y.; Wang, H.; Man, B.; Xiang, X.; Zhou, J.; Qiu, X.; Duan, Y.; Engel, A.S. The relationship between pH and bacterial communities in a single karst ecosystem and its implication for soil acidification. Front. Microbiol. 2016, 7. [CrossRef] [PubMed]

41. Park, S.; Cho, Y.-J.; Jung, D.; Jo, K.; Lee, E.-J.; Lee, J.-S. Microbial Diversity in Moonmilk of Baeg-nyong Cave, Korean CZO. Front. Microbiol. 2020, 11, 613. [CrossRef] [PubMed]

42. Saiz-Jimenez, C. The Microbiology of Show Caves, Mines, Tunnels, and Tombs: Implications for Management and Conservation. In Microbial Life of Cave Systems; DE GRUYTER: Berlin, Germany, 2015.

43. Jurado, V.; del Rosal, Y.; Gonzalez-Pimentel, J.L.; Hermosin, B.; Saiz-Jimenez, C. Biological control of phototrophic biofilms in a show cave: The case of nerja cave. Appl. Sci. 2020, 10, 3448. [CrossRef]

44. Garcia, M.G.; Moya, M.; Spilde, M.N. Discovering new diversity in Hawaiian lava tube microbial mats. In Proceedings of the 15th International Congress of Speleology, Kerrvile, TX, USA, 19-26 July 2009; pp. 364-369.

45. Hathaway, J.J.M. Molecular Phylogenetic Investigation of Microbial Diversity and Nitrogen Cycling in Lava Tubes. Master's Thesis, The University of New Mexico, Albuquerque, NM, USA, 2010.

46. Busse, H.J. Review of the taxonomy of the genus Arthrobacter, emendation of the genus arthrobacter sensu lato, proposal to reclassify selected species of the genus Arthrobacter in the novel genera Glutamicibacter gen. Nov., Paeniglutamicibacter gen. nov., Pseudogluta. Int. J. Syst. Evol. Microbiol. 2016, 66, 9-37. [CrossRef]

47. Borodina, E.; Kelly, D.P.; Schumann, P.; Rainey, F.A.; Ward-Rainey, N.L.; Wood, A.P. Enzymes of dimethylsulfone metabolism and the phylogenetic characterization of the facultative methylotrophs Arthrobacter sulfonivorans sp. nov., Arthrobacter methylotrophus sp. nov., and Hyphomicrobium sulfonivorans sp. nov. Arch. Microbiol. 2002, 177, 173-183. [CrossRef]

48. Zhang, H.; Sun, H.; Yang, R.; Li, S.; Zhou, M.; Gao, T.; An, L.; Chen, X.; Dyson, P. Complete genome sequence of a psychotrophic Pseudarthrobacter sulfonivorans strain Ar51 (CGMCC 4.7316), a novel crude oil and multi benzene compounds degradation strain. J. Biotechnol. 2016, 231, 81-82. [CrossRef]

49. Dedysh, S.N.; Didriksen, A.; Danilova, O.V.; Belova, S.E.; Liebner, S.; Svenning, M.M. Methylocapsa palsarum sp. nov., a methanotroph isolated from a subarctic discontinuous permafrost ecosystem. Int. J. Syst. Evol. Microbiol. 2015, 65, 3618-3624. [CrossRef]

50. Fernandez-Cortes, A.; Cuezva, S.; Alvarez-Gallego, M.; Garcia-Anton, E.; Pla, C.; Benavente, D.; Jurado, V.; Saiz-Jimenez, C.; Sanchez-Moral, S. Subterranean atmospheres may act as daily methane sinks. Nat. Commun. 2015, 6, 1-11. [CrossRef]

51. Webster, K.; Schimmelmann, A.; Drobniak, A.; Mastalerz, M.; Lagarde, L.R.; Boston, P.; Lennon, J. Diversity and composition of cave methanotrophic communities. bioRxiv 2018, 412213. [CrossRef]

52. Martineau, C.; Mauffrey, F.; Villemur, R. Comparative analysis of denitrifying activities of Hyphomicrobium nitrativorans, Hyphomicrobium denitrificans, and Hyphomicrobium zavarzinii. Appl. Environ. Microbiol. 2015, 81, 5003-5014. [CrossRef] [PubMed]

53. Manolache, E.; Onac, B. Geomicrobiology of Black Sediments in Vântului Cave (Romania): Preliminary Results. Cave Karst Sci. 2000, 27, 109-112.

54. De Bruijn, I.; Cheng, X.; de Jager, V.; Expósito, R.G.; Watrous, J.; Patel, N.; Postma, J.; Dorrestein, P.C.; Kobayashi, D.; Raaijmakers, J.M. Comparative genomics and metabolic profiling of the genus Lysobacter. BMC Genom. 2015, 16, 991. [CrossRef] 
55. Kumar, H.K.S.; Gan, H.M.; Tan, M.H.; Eng, W.W.H.; Barton, H.A.; Hudson, A.O.; Savka, M.A. Genomic characterization of eight Ensifer strains isolated from pristine caves and a whole genome phylogeny of Ensifer (Sinorhizobium). J. Genom. 2017, 5, 12-15. [CrossRef]

56. Hatayama, K.; Saito, K. Calcite formation induced by Ensifer adhaerens, Microbacterium testaceum, Paeniglutamicibacter kerguelensis, Pseudomonas protegens and Rheinheimera texasensis. Antonie Leeuwenhoek 2019, 112, 711-721. [CrossRef]

57. Zhao, C.T.; Wang, E.T.; Zhang, Y.M.; Chen, W.F.; Sui, X.H.; Chen, W.X.; Liu, H.C.; Zhang, X.X. Mesorhizobium silamurunense sp. nov., isolated from root nodules of astragalus species. Int. J. Syst. Evol. Microbiol. 2012, 62, 2180-2186. [CrossRef] [PubMed]

58. Díaz Herráiz, M. Caracterización de Comunidades Microbianas en Tumbas Etruscas y Romanas. Ph.D. Thesis, Universidad de Sevilla, Sevilla, Spain, 2015.

59. Yao, R.; Wang, R.; Wang, D.; Su, J.; Zheng, S.; Wang, G. Paenibacillus selenitireducens sp. nov., a selenite-reducing bacterium isolated from a selenium mineral soil. Int. J. Syst. Evol. Microbiol. 2014, 64, 805-811. [CrossRef]

60. Floor, G.H. Selenium Cycling in Volcanic Environments: The Role of Soils as Reactive Interfaces. Ph.D. Thesis, University of Girona, Girona, Spain, 2011.

61. Lin, S.Y.; Wu, Y.H.; Hameed, A.; Liu, Y.C.; Young, C.C. Ammoniphilus resinae sp. Nov., an endosporeforming bacterium isolated from resin fragments. Int. J. Syst. Evol. Microbiol. 2016, 66, 3010-3016. [CrossRef]

62. Domínguez Moñino, I. Evaluación y Control de Comunidades Microbianas en Cuevas Turísticas. Ph.D. Thesis, Universidad de Sevilla, Sevilla, Spain, 2015.

63. Martin-Sanchez, P.M.; Jurado, V.; Porca, E.; Bastian, F.; Lacanette, D.; Alabouvette, C.; Saiz-Jimenez, C. Airborne microorganisms in Lascaux Cave (France). Int. J. Speleol. 2014, 43, 295-303. [CrossRef]

64. Bastian, F.; Alabouvette, C.; Saiz-Jimenez, C. Bacteria and free-living amoeba in the Lascaux Cave. Res. Microbiol. 2009, 160, 38-40. [CrossRef] [PubMed]

65. Fernandez-Cortes, A.; Cuezva, S.; Sanchez-Moral, S.; Cañaveras, J.C.; Porca, E.; Jurado, V.; Martin-Sanchez, P.M.; Saiz-Jimenez, C. Detection of human-induced environmental disturbances in a show cave. Environ. Sci. Pollut. Res. 2011, 18, 1037-1045. [CrossRef] [PubMed]

66. Michel, A.J.; Ward, L.M.; Goffredi, S.K.; Dawson, K.S.; Baldassarre, D.T.; Brenner, A.; Gotanda, K.M.; McCormack, J.E.; Mullin, S.W.; O'Neill, A.; et al. The gut of the finch: Uniqueness of the gut microbiome of the Galápagos vampire finch. Microbiome 2018, 6, 167. [CrossRef] [PubMed]

67. Ghosh, W.; Bagchi, A.; Mandal, S.; Dam, B.; Roy, P. Tetrathiobacter kashmirensis gen. nov., sp. nov., a novel mesophilic, neutrophilic, tetrathionate-oxidizing, facultatively chemolithotrophic betaproteobacterium isolated from soil from a temperate orchard in Jammu and Kashmir, India. Int. J. Syst. Evol. Microbiol. 2005, 55, 1779-1787. [CrossRef]

68. Wang, X.; Jin, D.; Zhou, L.; Wu, L.; An, W.; Zhao, L. Draft Genome Sequence of Advenella kashmirensis Strain W13003, a Polycyclic Aromatic Hydrocarbon-Degrading Bacterium. Genome Announc. 2014, 2, 3-14. [CrossRef]

69. Cortés-Lorenzo, C.; del Mar Sánchez-Peinado, M.; Oliver-Rodríguez, B.; Vílchez, J.L.; González-López, J.J.; Rodríguez-Díaz, M. Two novel strains within the family Caulobacteraceae capable of degradation of linear alkylbenzene sulfonates as pure cultures. Int. Biodeterior. Biodegrad. 2013, 85, 62-65. [CrossRef]

70. Huber, K.J.; Geppert, A.M.; Wanner, G.; Fösel, B.U.; Wüst, P.K.; Overmann, J. The first representative of the globally widespread subdivision 6 Acidobacteria, Vicinamibacter silvestris gen. nov., sp. nov., isolated from subtropical savannah soil. Int. J. Syst. Evol. Microbiol. 2016, 66, 2971-2979. [CrossRef]

71. Vieira, S.; Luckner, M.; Wanner, G.; Overmann, J. Luteitalea pratensis gen. nov., sp. nov. a new member of subdivision 6 Acidobacteria isolated from temperate grassland soil. Int. J. Syst. Evol. Microbiol. 2017, 67, 1408-1414. [CrossRef]

72. Bárta, J.; Tahovská, K.; Šantrůčková, H.; Oulehle, F. Microbial communities with distinct denitrification potential in spruce and beech soils differing in nitrate leaching. Sci. Rep. 2017, 7, 9738. [CrossRef]

73. Eichorst, S.A.; Trojan, D.; Roux, S.; Herbold, C.; Rattei, T.; Woebken, D. Genomic insights into the Acidobacteria reveal strategies for their success in terrestrial environments. Environ. Microbiol. 2018, 20, 1041-1063. [CrossRef]

74. Hu, D.; Zang, Y.; Mao, Y.; Gao, B. Identification of Molecular Markers That Are Specific to the Class Thermoleophilia. Front. Microbiol. 2019, 10, 1185. [CrossRef] [PubMed] 
75. Perry, J.J. Thermoleophilum. In Bergey's Manual of Systematics of Archaea and Bacteria; Wiley: Hoboken, NJ, USA, 2015; pp. 1-6.

76. Yakimov, M.M.; Lünsdorf, H.; Golyshin, P.N. Thermoleophilum album and Thermoleophilum minutum are culturable representations of group 2 of the Rubrobacteridae (Actinobacteria). Int. J. Syst. Evol. Microbiol. 2003, 53, 377-380. [CrossRef] [PubMed]

77. Velasco, A.G.V.; Kowalchuk, G.A.; Mañero, F.J.G.; Ramos, B.; Yergeau, E.; García, J.A.L. Increased microbial activity and nitrogen mineralization coupled to changes in microbial community structure in the rhizosphere of Bt corn. Appl. Soil Ecol. 2013, 68, 46-56. [CrossRef]

78. Bartelme, R.P.; Custer, J.M.; Dupont, C.L.; Espinoza, J.L.; Torralba, M.; Khalili, B.; Carini, P. Influence of Substrate Concentration on the Culturability of Heterotrophic Soil Microbes Isolated by High-Throughput Dilution-to-Extinction Cultivation. mSphere 2020, 5. [CrossRef]

79. Yu, B.; Liu, C.; Wang, S.; Wang, W.; Zhao, S.; Zhu, G. Applying constructed wetland-microbial electrochemical system to enhance $\mathrm{NH}^{4+}$ removal at low temperature. Sci. Total Environ. 2020, 724, 138017. [CrossRef]

80. Kushkevych, I.; Kobzová, E.; Vítězová, M.; Vítěz, T.; Dordević, D.; Bartoš, M. Acetogenic microorganisms in operating biogas plants depending on substrate combinations. Biologia 2019, 74, 1229-1236. [CrossRef]

81. Brzeszcz, J.; Kapusta, P.; Steliga, T.; Turkiewicz, A. Hydrocarbon removal by two differently developed microbial inoculants and comparing their actions with biostimulation treatment. Molecules 2020, $25,661$. [CrossRef]

82. Itoh, T.; Yamanoi, K.; Kudo, T.; Ohkuma, M.; Takashina, T. Aciditerrimonas ferrireducens gen. nov., sp. nov., an iron-reducing thermoacidophilic actinobacterium isolated from a solfataric field. Int. J. Syst. Evol. Microbiol. 2011, 61, 1281-1285. [CrossRef]

83. Honeker, L.K.; Gullo, C.F.; Neilson, J.W.; Chorover, J.; Maier, R.M. Effect of Re-acidification on Buffalo Grass Rhizosphere and Bulk Microbial Communities during Phytostabilization of Metalliferous Mine Tailings. Front. Microbiol. 2019, 10, 1209. [CrossRef]

84. Huang, S.; Jaffé, P.R. Isolation and characterization of an ammonium-oxidizing iron reducer: Acidimicrobiaceae sp. A6. PLoS ONE 2018. [CrossRef]

85. Zhu, H.Z.; Zhang, Z.F.; Zhou, N.; Jiang, C.Y.; Wang, B.J.; Cai, L.; Liu, S.J. Diversity, distribution and co-occurrence patterns of bacterial communities in a karst cave system. Front. Microbiol. 2019, 10, 1726. [CrossRef] [PubMed]

86. Zhang, C.; Tayyab, M.; Abubakar, A.Y.; Yang, Z.; Pang, Z.; Islam, W.; Lin, Z.; Li, S.; Luo, J.; Fan, X.; et al. Bacteria with Different Assemblages in the Soil Profile Drive the Diverse Nutrient Cycles in the Sugarcane Straw Retention Ecosystem. Diversity 2019, 11, 194. [CrossRef]

87. Fawaz, M. Revealing the Ecological Role of Gemmatimonadetes Through Cultivation and Molecular Analysis of Agricultural Soils. Master's Thesis, University of Tennessee, Knoxville, TN, USA, May 2013.

Publisher's Note: MDPI stays neutral with regard to jurisdictional claims in published maps and institutional affiliations.

(C) 2020 by the authors. Licensee MDPI, Basel, Switzerland. This article is an open access article distributed under the terms and conditions of the Creative Commons Attribution (CC BY) license (http://creativecommons.org/licenses/by/4.0/). 